\title{
Antifungal cyclic peptides from the marine sponge Microscleroderma herdmani
}

This article was published in the following Dove Press journal:

Research and Reports in Medicinal Chemistry

16 May 2012

Number of times this article has been viewed

\section{Xiaohui Zhang' \\ Melissa R Jacob' \\ R Ranga Rao' \\ Yan-Hong Wang' \\ Ameeta K Agarwal' \\ David J Newman ${ }^{2}$ \\ Ikhlas A Khan ${ }^{1,3}$ \\ Alice M Clark ${ }^{1,3}$ \\ Xing-Cong $\mathrm{Li}^{1,3}$}

'National Center for Natural

Products Research, Research Institute

of Pharmaceutical Sciences, School

of Pharmacy, The University of

Mississippi, University, MS, ${ }^{2}$ Natural

Products Branch, Developmental

Therapeutics Program, Division of

Cancer Treatment and Diagnosis,

National Cancer Institute - Frederick,

Frederick, MD, ${ }^{3}$ Department of

Pharmacognosy, School of Pharmacy,

The University of Mississippi,

University, MS, USA
Correspondence: Xing-Cong Li National Center for Natural Products Research, Research Institute of Pharmaceutical Sciences, and Department of Pharmacognosy, School of Pharmacy,

The University of Mississippi, University,

MS, 38677, USA

Tel + I 6629156742

Fax + I 6629157989

Email xcli7@olemiss.edu
Abstract: Screening natural product extracts from the National Cancer Institute Open Repository for antifungal discovery afforded hits for bioassay-guided fractionation. Using LC-MS analysis to generate chemical structure information on potentially active compounds, two new cyclic hexapeptides, microsclerodermins $\mathrm{J}$ (1) and K (2), were isolated from the deep-water sponge Microscleroderma herdmani, along with microsclerodermins A (3) and B (4), previously isolated from an unidentified Microscleroderma species. The structures of the new compounds were elucidated by spectroscopic analysis and chemical methods. In vitro antifungal testing showed that the four compounds possessed strong activities against the opportunistic fungal pathogens Candida albicans, Candida glabrata, Candida krusei, Cryptococcus neoformans, and Aspergillus fumigatus.

Keywords: antifungal, microsclerodermins, Microscleroderma herdmani, opportunistic fungal pathogens

\section{Introduction}

Systemic mycoses caused by opportunistic fungal pathogens have increased over the past two decades. ${ }^{1,2}$ However, there are a limited number of antifungal drugs available in the current antifungal therapy, and resistance has been found in all antifungal drug classes. ${ }^{3}$ This highlights the need for the discovery of safer, broad-spectrum antifungal agents, preferably with novel modes of action.

To diversify the collection of antifungal scaffolds from natural sources is an important approach for antifungal drug discovery. As part of our antifungal discovery program, we have screened thousands of natural product extracts from marine organisms, microbes, and plants from the National Cancer Institute Open Repository. An organic extract from the deep-water sponge Microscleroderma herdmani, collected in Mauritius, showed potent in vitro antifungal activity against Candida albicans, Cryptococcus neoformans, and Aspergillus fumigatus, three opportunistic fungal pathogens that may cause life-threatening systemic mycoses in immunosuppressed hosts, such as AIDS and cancer patients. ${ }^{4}$ Although microsclerodermins, as a class of cyclic hexapeptides, have been isolated from Microscleroderma sp. and Theonella sp. and have been shown to possess antifungal and antitumor activities, ${ }^{5-7}$ the presence of possible new microsclerodermin analogs in this sponge was indicated by preliminary LC-MS analysis. The new compounds might be responsible for the observed antifungal activity, prompting us to perform a bioassay-guided isolation. As a result, two new cyclic hexapeptides, microsclerodermins J (1) and K (2), were isolated, along with 
the known microsclerodermins A (3) and B (4) (Figure 1). Herein, we report the isolation, structure elucidation, and in vitro antifungal activities of the four compounds.

\section{Results and discussion}

The organic extract of the sponge $M$. herdmani, obtained from the Natural Products Branch Repository Program at the National Cancer Institute (NCI), showed potent antifungal activities against $C$. albicans, $C$. neoformans, and $A$. fumigatus, with $50 \%$ growth inhibitory concentrations $\left(\mathrm{IC}_{50} \mathrm{~s}\right)$ of 4.0, 3.0, and $3.5 \mu \mathrm{g} / \mathrm{mL}$, respectively. Fractionation of this extract by reversed-phase silica gel column chromatography afforded

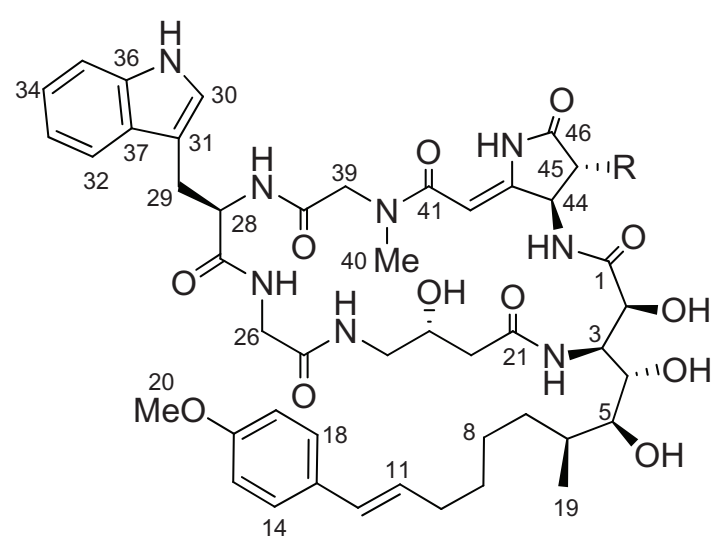

$\begin{array}{ll} & \mathrm{R} \\ 1 & \mathrm{H} \\ 2 & \mathrm{OH}\end{array}$

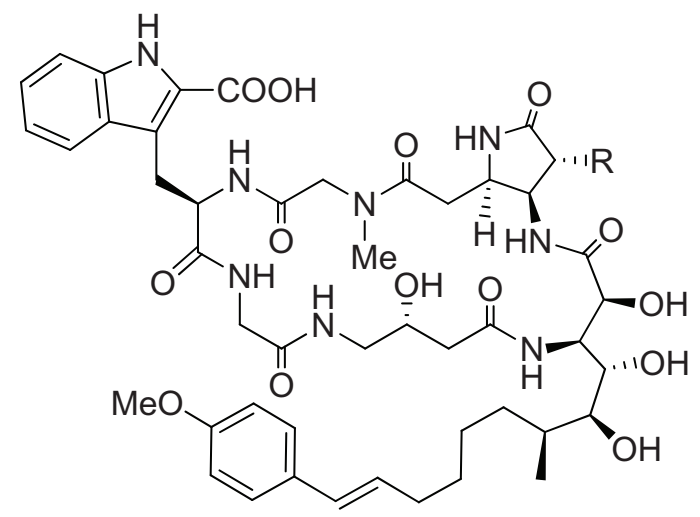

$\mathrm{R}$

$3 \mathrm{OH}$

$4 \mathrm{H}$

Figure I Structures of compounds I-4. active fractions that were analyzed by LC-MS. The known compounds microsclerodermins A (3) and B (4), previously isolated from Microscleroderma sp., were identified in one active fraction, and subsequent separation by reversed-phase HPLC afforded compounds 3 and 4, whose structures were confirmed by NMR spectroscopy. In another active fraction, LC-MS indicated the presence of two major compounds with retention times of 16.12 and $16.51 \mathrm{~min}$, corresponding to strong quasimolecular ion peaks at $m / z$ 933.17 $[\mathrm{M}+\mathrm{H}]^{+}$ and $917.29[\mathrm{M}+\mathrm{H}]^{+}$, respectively, in their positive ion mode ESIMS spectra (Figure 2). In addition, two minor quasimolecular ion peaks at $m / z$ 955.38 $[\mathrm{M}+\mathrm{Na}]^{+}$and 939.45 $[\mathrm{M}+\mathrm{Na}]^{+}$were observed for the two compounds. Thus, the molecular weights of the two compounds were deduced as 932 and 916, respectively, which do not match the molecular weights of previously reported microsclerodermins A-I, dehydromicrosclerodermin $\mathrm{A}$, and dehydromicrosclerodermins $\mathrm{C}$ and $\mathrm{D},{ }^{5-7}$ potentially indicating new microsclerodermins. The UV spectra of these two compounds showed strong absorptions around 205 and $261.5 \mathrm{~nm}$ and a shoulder at $290 \mathrm{~nm}$ (Figure 2), similar to those of microsclerodermins A and B. ${ }^{5}$ This fraction was then subjected to reversed-phase HPLC separation to furnish compounds $\mathbf{1}$ and $\mathbf{2}$, corresponding to the peaks with retention times of 16.51 and 16.12 minutes, respectively, in the LC-MS base peak chromatogram (Figure 2).

Compound 1 was obtained as an amorphous white powder, with the molecular formula $\mathrm{C}_{46} \mathrm{H}_{60} \mathrm{~N}_{8} \mathrm{O}_{12}$, determined by a combination of high resolution ESIMS $(\mathrm{m} / \mathrm{z} 917.4528$ for $[\mathrm{M}+\mathrm{H}]^{+}$) and ${ }^{13} \mathrm{C}$ NMR spectra. Its ${ }^{1} \mathrm{H}$ NMR spectroscopic data in DMSO- $d_{6}$ (Table 1) displayed resonance signals of five amide $\mathrm{NH}$ at $\delta 7.12(\mathrm{~d}, J=9.0 \mathrm{~Hz}, \mathrm{NH} 3), 7.40$ (m, NH24), 8.35 (d, $J=10.0 \mathrm{~Hz}, \mathrm{NH} 44), 8.38$ (dd, $J=5.5,6.5 \mathrm{~Hz}$, $\mathrm{NH} 26)$, and $8.70(\mathrm{~d}, J=5.0 \mathrm{~Hz}, \mathrm{NH} 28)$; an $N$-methyl group at $\delta 3.00$ (s, C-40); an indole NH at $\delta 10.87$ (s, N36); and an $N$-vinylacylamide $\mathrm{NH}$ at $\delta 10.42$ (s, NH43), accounting for all eight nitrogen atoms. The ${ }^{13} \mathrm{C}$ NMR spectroscopic data (Table 1) indicated the presence of seven carbonyl carbons at $\delta 168.1$ (C-41), 168.9 (C-25), 170.9 (C-38), 171.5 (C-27), 172.4 (C-21), 174.1 (C-1), and 174.9 (C-46); four methines attached to hydroxy groups at $\delta 68.4$ (C-4), 67.1 (C-23), 69.4 (C-2), and 72.8 (C-5); and one methoxy group at $\delta 55.1$, making up all twelve oxygen atoms in the molecule. These NMR spectroscopic characteristics implied that compound $\mathbf{1}$ should be a member of the microsclerodermin family. ${ }^{5-7}$

Comparison of its ${ }^{1} \mathrm{H}$ and ${ }^{13} \mathrm{C}$ NMR data (Table 1) with those of reported microsclerodermins readily identified three amino acid residues, glycine (Gly), N-methyl 
A

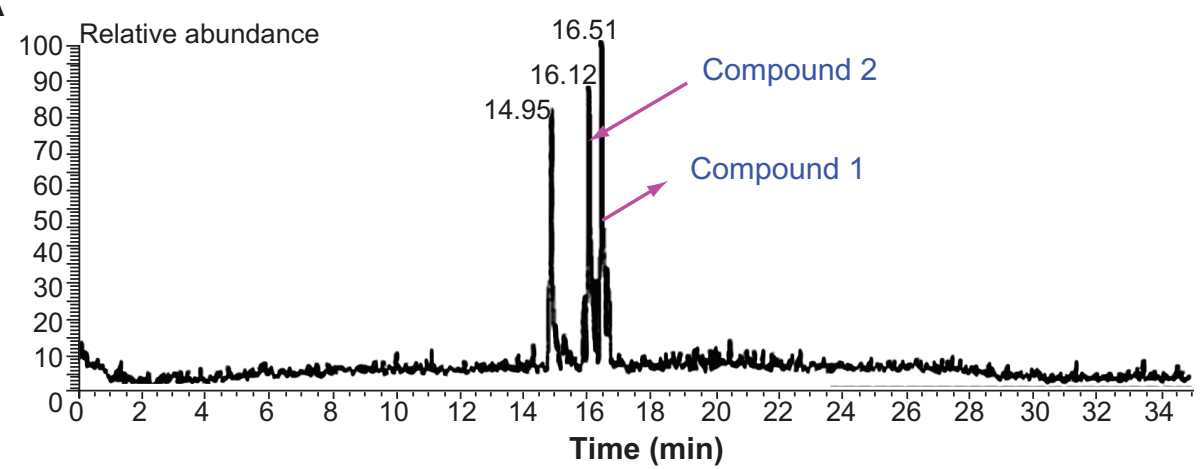

B

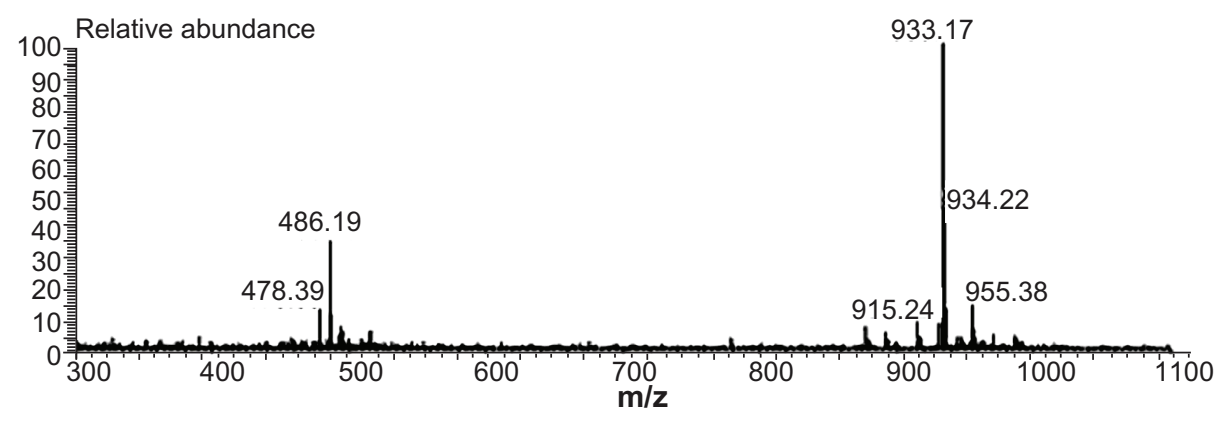

C

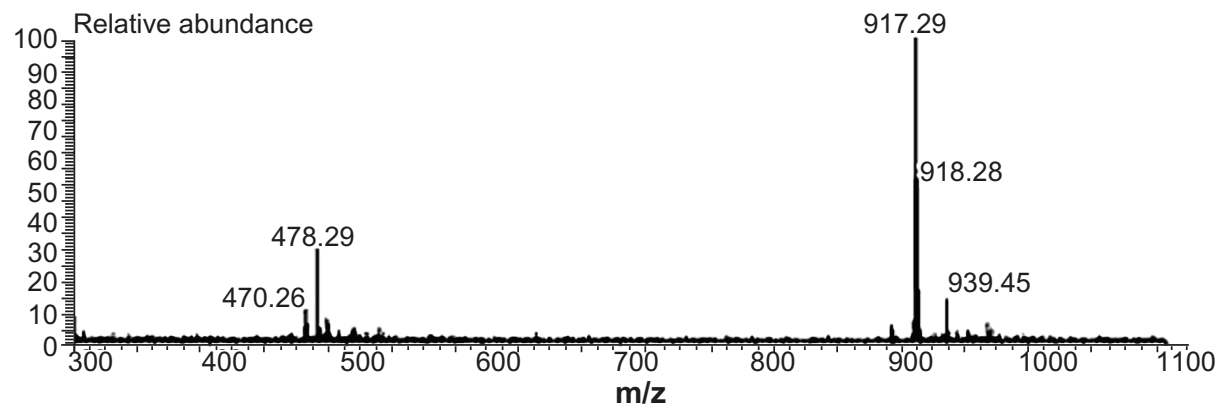

D
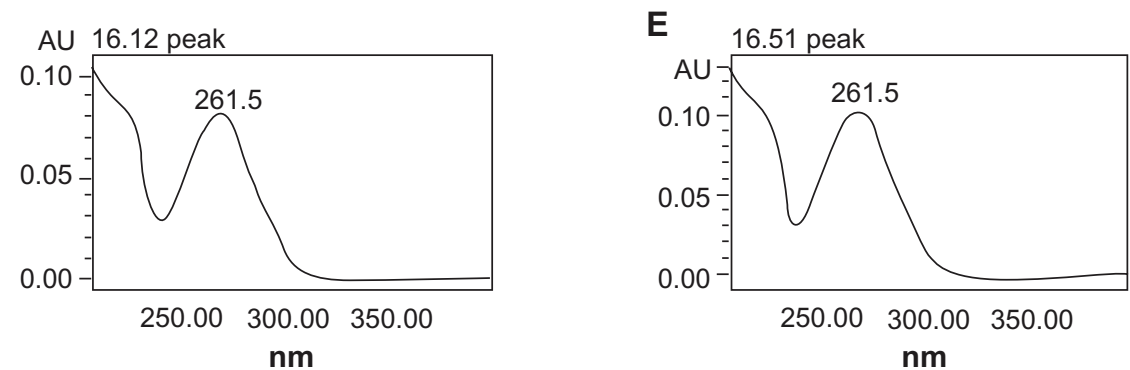

Figure 2 LC-MS analysis of antifungal column fraction D: (A) base peak chromatogram (BPC); (B) positive ESIMS spectrum for the peak with a retention time of I6.I2 minutes, corresponding to compound 2; (C) positive ESIMS spectrum for the peak with a retention time of I6.5I minutes, corresponding to compound I; (D) UV spectrum for the peak with a retention time of 16.12 minutes, corresponding to compound 2; and (E) UV spectrum for the peak with a retention time of I6.5I minutes, corresponding to compound $\mathbf{I}$.

glycine (NMeGly), and 4-amino-3-hydroxybutyric acid or gamma-amino-beta-hydroxybutyric acid (GABOB) moieties, which were invariable building blocks in all reported microsclerodermins. ${ }^{5-7}$ The presence of 3-amino-6-methyl12-(p-methoxyphenyl)-2,4,5-trihydroxy-dodec-11-enoic acid (AMMTD), a unique amino acid residue present in microsclerodermins $\mathrm{A}$ and $\mathrm{B},{ }^{5}$ was evident by the resonance signals of an aromatic ring $\left[\delta_{\mathrm{H} / \mathrm{C}} 7.31(\mathrm{~d}, J=8.5 \mathrm{~Hz}) / 126.9\right.$ and $\left.\delta_{\mathrm{H} / \mathrm{C}} 6.86(\mathrm{~d}, J=8.5 \mathrm{~Hz}) / 113.9\right]$, one $E$-double bond $\left[\delta_{\mathrm{H} / \mathrm{C}} 6.12(\mathrm{~m}) / 128.4, \delta_{\mathrm{H} / \mathrm{C}} 6.32(\mathrm{~d}, J=16.0 \mathrm{~Hz}) / 128.9\right]$, three oxygen-bearing methines $\left[\delta_{\mathrm{H} / \mathrm{C}} 4.43(\mathrm{~d}, J=4.0 \mathrm{~Hz}) / 69.4\right.$, $\delta_{\mathrm{H} / \mathrm{C}} 3.48(\mathrm{brs}) / 68.4$, and $\left.\delta_{\mathrm{H} / \mathrm{C}} 3.07(\mathrm{~m}) / 72.8\right]$, four methylenes $\left(\delta_{\mathrm{C}} 25.9,29.5,32.5\right.$, and 32.8$)$, and one methoxy group $\left[\delta_{\mathrm{H} / \mathrm{C}} 3.74(\mathrm{~s}) / 55.1\right]$. DQF-COSY spectrum further confirmed the connections in the long aliphatic chain from C-2 to C-12. Eight aromatic carbons $\left(\delta_{\mathrm{C}} 110.0,111.4,118.1,118.4,121.0\right.$, 
Table I NMR spectroscopic data of compounds I and $\mathbf{2}$ in DMSO- $d_{6}(\delta, \text { PPm })^{\mathrm{a}}$

\begin{tabular}{|c|c|c|c|c|}
\hline \multirow[t]{2}{*}{ Amino acid } & \multicolumn{2}{|l|}{$I$} & \multicolumn{2}{|l|}{2} \\
\hline & $\delta_{c}$, mult & $\delta_{H}(J$ in $\mathbf{H z})$ & $\delta_{c}$, mult & $\delta_{\mathrm{H}}(J$ in $\mathrm{Hz})$ \\
\hline \multicolumn{5}{|l|}{ AMMTD } \\
\hline 1 & $174.1 \mathrm{~s}$ & & $174.0 \mathrm{~s}$ & \\
\hline 2 & $69.4 \mathrm{~d}$ & $4.43(\mathrm{~d}, 4.0)$ & $69.4 \mathrm{~d}$ & $4.48(\mathrm{~m})$ \\
\hline 3 & $53.7 \mathrm{~d}$ & $4.11(m)$ & $53.7 \mathrm{~d}$ & $4.10(\mathrm{~m})$ \\
\hline 4 & $68.4 \mathrm{~d}$ & 3.48 (br s) & $68.5 \mathrm{~d}$ & 3.48 (br s) \\
\hline 5 & $72.8 \mathrm{~d}$ & $3.07(\mathrm{~m})$ & $72.8 \mathrm{~d}$ & $3.07(\mathrm{~m})$ \\
\hline 6 & $34.0 \mathrm{~d}$ & $1.59(\mathrm{~m})$ & $34.5 \mathrm{~d}$ & $\mathrm{I} .59(\mathrm{~m})$ \\
\hline 7 & $32.8 \mathrm{t}$ & $2.16(\mathrm{br} \mathrm{s})$ & $32.6 \mathrm{t}$ & $2.14(\mathrm{br} \mathrm{s})$ \\
\hline \multirow[t]{2}{*}{8} & $25.9 \mathrm{t}$ & 1.24 (br s) & $26.0 \mathrm{t}$ & 1.23 (br s) \\
\hline & & $\mathrm{I} .40(\mathrm{~m})$ & & $\mathrm{I} .40(\mathrm{~m})$ \\
\hline 9 & $29.5 \mathrm{t}$ & 1.24 (br s) & $29.5 \mathrm{t}$ & 1.23 (br s) \\
\hline 10 & $32.5 \mathrm{t}$ & $2.16(\mathrm{br} \mathrm{s})$ & $32.4 \mathrm{t}$ & $2.14(\mathrm{br} \mathrm{s})$ \\
\hline 11 & $128.4 \mathrm{~d}$ & $6.12(\mathrm{~m})$ & $128.4 \mathrm{~d}$ & $6.12(\mathrm{~m})$ \\
\hline 12 & $128.9 \mathrm{~d}$ & $6.32(\mathrm{~d}, 16.0)$ & $128.9 d$ & $6.31(\mathrm{~d}, 15.5)$ \\
\hline 13 & $130.1 \mathrm{~s}$ & & $130.1 \mathrm{~s}$ & \\
\hline 14 & $126.9 \mathrm{~d}$ & $7.31(\mathrm{~d}, 8.5)$ & $126.9 \mathrm{~d}$ & $7.30(\mathrm{~d}, 8.5)$ \\
\hline 15 & $113.9 \mathrm{~d}$ & $6.86(\mathrm{~d}, 8.5)$ & $113.9 \mathrm{~d}$ & $6.85(\mathrm{~d}, 8.0)$ \\
\hline 16 & $158.3 \mathrm{~s}$ & & $158.3 \mathrm{~s}$ & \\
\hline 17 & $113.9 \mathrm{~d}$ & $6.86(\mathrm{~d}, 8.5)$ & $113.9 d$ & $6.85(\mathrm{~d}, 8.0)$ \\
\hline 18 & $126.9 \mathrm{~d}$ & $7.31(\mathrm{~d}, 8.5)$ & $126.9 \mathrm{~d}$ & $7.30(\mathrm{~d}, 8.5)$ \\
\hline 19 & $15.9 \mathrm{q}$ & $0.78(\mathrm{~d}, 6.5)$ & $15.4 \mathrm{q}$ & $0.77(\mathrm{~d}, 6.5)$ \\
\hline 20 & $55.1 \mathrm{q}$ & $3.74(\mathrm{~s})$ & $55.0 \mathrm{q}$ & $3.72(\mathrm{~s})$ \\
\hline $\mathrm{NH} 3$ & & $7.12(\mathrm{~d}, 9.0)$ & & $7.20(\mathrm{~d}, 9.5)$ \\
\hline $\mathrm{OH} 2$ & & 6.12 & & 6.23 \\
\hline $\mathrm{OH} 4$ & & 4.28 & & 4.34 \\
\hline $\mathrm{OH} 5$ & & 4.26 & & 4.43 \\
\hline \multicolumn{5}{|l|}{ GABOB } \\
\hline 21 & $172.4 \mathrm{~s}$ & & $172.4 \mathrm{~s}$ & \\
\hline \multirow[t]{2}{*}{22} & $41.4 \mathrm{t}$ & $2.06(\mathrm{dd}, \mathrm{I} \mid .0,13.5)$ & $41.5 \mathrm{t}$ & $2.09(\mathrm{~m})$ \\
\hline & & $2.34(\mathrm{~d}, \mathrm{I} 3.5)$ & & $2.33(\mathrm{~d}, \mathrm{I} 4.5)$ \\
\hline 23 & $67.1 \mathrm{~d}$ & $3.72(\mathrm{~m})$ & $66.6 \mathrm{~d}$ & $3.79(\mathrm{~m})$ \\
\hline \multirow[t]{2}{*}{24} & $45.7 \mathrm{t}$ & $2.77(\mathrm{~m})$ & $45.3 \mathrm{t}$ & $2.73(\mathrm{~m})$ \\
\hline & & $3.37(\mathrm{~m})$ & & $3.32(\mathrm{~m})$ \\
\hline $\mathrm{NH} 24$ & & $7.40(\mathrm{~m})$ & & $7.38(\mathrm{~m})$ \\
\hline $\mathrm{OH} 23$ & & Not detected & & \\
\hline \multicolumn{5}{|l|}{ Gly } \\
\hline 25 & $168.9 \mathrm{~s}$ & & $169.0 \mathrm{~s}$ & \\
\hline \multirow[t]{2}{*}{26} & $42.8 \mathrm{t}$ & $3.68(\mathrm{dd}, 5.5,17.0)$ & $42.6 \mathrm{t}$ & $3.66(\mathrm{dd}, 5.5,16.5)$ \\
\hline & & $3.55(\mathrm{dd}, 5.5,17.0)$ & & $3.55(\mathrm{dd}, 5.5,16.5)$ \\
\hline $\mathrm{NH} 26$ & & $8.38(t, 5.5,6.5)$ & & $8.38(\mathrm{~m})$ \\
\hline \multicolumn{5}{|l|}{ Trp } \\
\hline 27 & $171.5 \mathrm{~s}$ & & $171.4 \mathrm{~s}$ & \\
\hline 28 & $55.7 \mathrm{~d}$ & $4.09(\mathrm{~m})$ & $55.6 \mathrm{~d}$ & $4.10(\mathrm{~m})$ \\
\hline \multirow[t]{2}{*}{29} & $25.7 \mathrm{t}$ & $3.09(\mathrm{~m})$ & $25.7 \mathrm{t}$ & $3.06(\mathrm{~m})$ \\
\hline & & $3.23(\mathrm{~m})$ & & $3.24(\mathrm{~d}, 4.5)$ \\
\hline 30 & $123.9 \mathrm{~d}$ & $7.24(\mathrm{~d}, 0.5)$ & $123.9 \mathrm{~d}$ & $7.21(\mathrm{~s})$ \\
\hline 31 & $110.0 \mathrm{~s}$ & & $110.0 \mathrm{~s}$ & \\
\hline 32 & $118.1 \mathrm{~d}$ & $7.54(\mathrm{~d}, 8.0)$ & $118.1 \mathrm{~d}$ & $7.52(\mathrm{~d}, 7.5)$ \\
\hline 33 & $118.4 \mathrm{~d}$ & 7.01 (dd, 7.0, 7.5) & $118.4 \mathrm{~d}$ & $7.00(\mathrm{dd}, 7.5,8.0)$ \\
\hline 34 & $121.0 \mathrm{~d}$ & $7.08(\mathrm{~d}, 7.5)$ & $121.0 \mathrm{~d}$ & 7.07 (dd, 7.5, 7.5) \\
\hline 35 & $111.4 \mathrm{~d}$ & $7.36(\mathrm{~d}, 8.0)$ & $111.4 \mathrm{~d}$ & $7.34(\mathrm{~d}, 8.0)$ \\
\hline 36 & $136.2 \mathrm{~s}$ & & $136.1 \mathrm{~s}$ & \\
\hline 37 & $127.5 \mathrm{~s}$ & & $127.0 \mathrm{~s}$ & \\
\hline $\mathrm{NH} 28$ & & $8.70(d, 5.0)$ & & $8.70(\mathrm{~d}, 5.0)$ \\
\hline $\mathrm{NH} 36$ & & $10.87(s)$ & & $10.85(s)$ \\
\hline
\end{tabular}


Table I (Continued)

\begin{tabular}{|c|c|c|c|c|}
\hline \multirow[t]{2}{*}{ Amino acid } & \multicolumn{2}{|l|}{ I } & \multicolumn{2}{|l|}{2} \\
\hline & $\delta_{c}$, mult & $\delta_{\mathrm{H}}(\mathrm{J}$ in $\mathrm{Hz})$ & $\delta_{c}$, mult & $\delta_{\mathrm{H}}(\mathrm{J}$ in $\mathrm{Hz})$ \\
\hline \multicolumn{5}{|l|}{ NMeGly } \\
\hline 38 & $170.9 \mathrm{~s}$ & & $170.7 \mathrm{~s}$ & \\
\hline \multirow[t]{2}{*}{39} & $50.0 \mathrm{t}$ & $4.57(\mathrm{~d}, \mathrm{I} 6.0)$ & $50.3 \mathrm{t}$ & $4.50(\mathrm{~d}, \mathrm{I7.5})$ \\
\hline & & $3.45(\mathrm{~d}, 16.0)$ & & $3.55(\mathrm{~m})$ \\
\hline 40 & $36.9 q$ & $3.00(s)$ & $37.0 q$ & $3.00(s)$ \\
\hline \multicolumn{5}{|l|}{ pyrrolidone } \\
\hline 41 & $168.1 \mathrm{~s}$ & & $167.9 \mathrm{~s}$ & \\
\hline 42 & $87.9 \mathrm{~d}$ & $5.26(\mathrm{br} \mathrm{s})$ & $88.4 \mathrm{~d}$ & $5.18(s)$ \\
\hline 43 & $157.4 \mathrm{~s}$ & & $152.3 \mathrm{~s}$ & \\
\hline 44 & $45.9 \mathrm{~d}$ & $5.24(\mathrm{~m})$ & $55.2 \mathrm{~d}$ & $4.82(\mathrm{dd}, 6.0,7.0)$ \\
\hline \multirow[t]{2}{*}{45} & $34.5 \mathrm{t}$ & $2.77(\mathrm{~m})$ & $71.3 \mathrm{~d}$ & $4.42(\mathrm{~m})$ \\
\hline & & $2.48(\mathrm{~m})$ & & \\
\hline 46 & $174.9 \mathrm{~s}$ & & $174.3 \mathrm{~s}$ & \\
\hline $\mathrm{NH} 43$ & & $10.42(\mathrm{~s})$ & & $10.42(s)$ \\
\hline $\mathrm{NH} 44$ & & $8.35(\mathrm{~d}, 10.0)$ & & $8.38(\mathrm{~m})$ \\
\hline $\mathrm{OH} 45$ & & & & 6.13 \\
\hline
\end{tabular}

Notes: ${ }^{2}$ Data recorded at $500 \mathrm{MHz}$ for ${ }^{1} \mathrm{H}$ NMR and $125 \mathrm{MHz}$ for ${ }^{13} \mathrm{C}$ NMR. Assignments were based on DEPT and 2D NMR, including DQF-COSY, HMQC, HMBC, and ROESY. Well-resolved couplings are expressed with coupling patterns and coupling constants in $\mathrm{Hz}$ in parentheses. For overlapped signals, only chemical shift values are given.

$123.9,127.5$, and 136.2$)$ and $\mathrm{NH}\left(\delta_{\mathrm{H}} 10.87\right)$ assembled an indole skeleton. $\mathrm{HMBC}$ correlations (Figure 3 ), from $\mathrm{H}-28$ $\left(\delta_{\mathrm{H}} 4.09\right)$ to $\mathrm{C}-30\left(\delta_{\mathrm{C}} 123.9\right)$ and $\mathrm{C}-27\left(\delta_{\mathrm{C}} 171.5\right)$, and from $\mathrm{H}-29\left(\delta_{\mathrm{H}} 3.09\right.$ and 3.23$)$ to $\mathrm{C}-28\left(\delta_{\mathrm{C}} 55.7\right), \mathrm{C}-30\left(\delta_{\mathrm{C}} 123.9\right)$, $\mathrm{C}-31\left(\delta_{\mathrm{C}} 110.0\right)$, and $\mathrm{C}-37\left(\delta_{\mathrm{C}} 127.5\right)$, confirmed the presence of tryptophan (Trp), which was also an amino acid residue in microsclerodermins $\mathrm{F}$ and $\mathrm{H} .{ }^{7}$ The last compositional amino acid residue was 3-hydroxy-4-amino-5-vinylpyrrolidone (pyrrolidone), which was indicated by the chemical shift of $\mathrm{NH}$ at $\delta 10.42$ (NH43) and HMBC correlations from this $\mathrm{NH}$ to $\mathrm{C}-43\left(\delta_{\mathrm{C}} 157.4\right), \mathrm{C}-44\left(\delta_{\mathrm{C}} 45.9\right), \mathrm{C}-45\left(\delta_{\mathrm{C}} 34.5\right)$, and C-46 $\left(\delta_{\mathrm{C}}\right.$ $174.9)$, and $\mathrm{H}-42\left(\delta_{\mathrm{H}} 5.26\right.$, brs) to $\mathrm{C}-41\left(\delta_{\mathrm{C}} 168.1\right)$ and $\mathrm{C}-44$ $\left(\delta_{C} 45.9\right)$. These chemical shifts are consistent with those of the same pyrrolidone moiety in microsclerodermin $\mathrm{E}^{6}{ }^{6}$

The HMBC correlations between NH44 and C-1, NMe40 and C-41, NH28 and C-38, NH26 and C-27, NH24 and C-25,

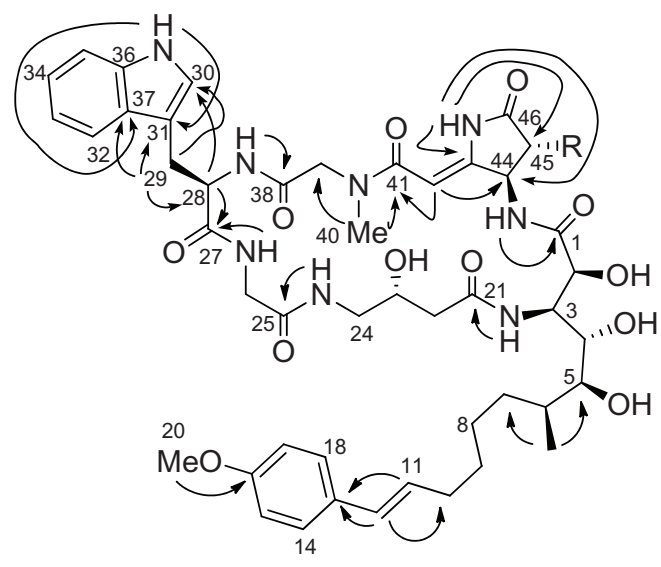

Figure $\mathbf{3}$ Key HMBC correlations for compounds I and $\mathbf{2}$. and NH3 and C21 (Figure 3) determined the cyclic peptide chain, starting from AMMTD to pyrrolidone-NMeGly-Trp-Gly and closed by GABOB. As the ${ }^{1} \mathrm{H}$ and ${ }^{13} \mathrm{C}$ NMR chemical shifts of individual amino acid residues are identical to those of structurally close anhydromicrosclerodermin C, except for the achiral aromatic moiety of tryptophan, ${ }^{6}$ the absolute configurations of these amino acids should be the same as those of previously reported microsclerodermins that share similar taxonomic sources..$^{5-7}$ The identical NMR data also suggest that these compounds should possess similar conformations. Compound $\mathbf{1}$ was named microsclerodermin J.

Compound 2, named microsclerodermin $\mathrm{K}$, has the molecular formula $\mathrm{C}_{46} \mathrm{H}_{60} \mathrm{~N}_{8} \mathrm{O}_{13}$, which was determined by the high-resolution ESIMS $\left(\mathrm{m} / \mathrm{z} 931.4124[\mathrm{M}-\mathrm{H}]^{-}\right)$and ${ }^{13} \mathrm{C}$ NMR spectra. Its NMR data (Table 2) are similar to those of compound 1. However, the observed significant downfield shifting of C-45 at $\delta_{\mathrm{C}} 71.3(\mathrm{~d})$ and $\mathrm{H}-45$ at $\delta_{\mathrm{C}} 4.42(\mathrm{~m})$ in $\mathbf{2}$, compared to $\mathbf{1}$, confirms that an $\alpha$-hydroxy group is attached at C-45, giving the same pyrrolidone moiety as in dehydromicrosclerodermin A. ${ }^{5}$ Complete acid hydrolysis of $\mathbf{2}$ was performed, and the resultant common amino acid residue tryptophan was determined to possess a $2 R$ absolute configuration, by Marfey's method. ${ }^{8}$ In conjunction with the NMR data, this further confirmed that the absolute configurations of the amino acid residues in $\mathbf{2}$, as well as in $\mathbf{1}$, should be the same as those of microsclerodermins A and B. ${ }^{5}$

Microsclerodermins J (1), K (2), A (3), and B (4) were tested for antifungal activity against $C$. albicans, C. glabrata, C. krusei, A. fumigatus, and C. neoformans, using the CLSI broth microdilution method. ${ }^{9,10}$ The minimum inhibitory 
Table 2 In vitro antifungal activity of compounds I-4 (IC $\left.{ }_{50} / \mathrm{MIC} / \mathrm{MFC}, \mu \mathrm{g} / \mathrm{mL}\right)^{\mathrm{a}}$

\begin{tabular}{|c|c|c|c|c|c|}
\hline & $\begin{array}{l}\text { C. albicans } \\
\text { ATTC } 90028\end{array}$ & $\begin{array}{l}\text { C. glabrata } \\
\text { ATCC } 90030\end{array}$ & $\begin{array}{l}\text { C. krusei } \\
\text { ATCC } 6258\end{array}$ & $\begin{array}{l}\text { A. fumigatus } \\
\text { ATCC } 90906\end{array}$ & $\begin{array}{l}\text { C. neoformans } \\
\text { ATCC } 90113\end{array}$ \\
\hline Microsclerodermin J (I) & $9.0 / 20.0 / 20.0$ & $11.0 / 20.0 / 20.0$ & $10.6 / 20.0 / 20.0$ & $5.3 / 10.0 /-^{b}$ & $5.2 / 10.0 / 10.0$ \\
\hline Microsclerodermin K (2) & $5.3 / 10.0 / 10.0$ & $5.7 / 10.0 / 10.0$ & $5.7 / 10.0 / 10.0$ & $4.5 / 10.0 /-^{b}$ & $2.7 / 5.0 / 5.0$ \\
\hline Microsclerodermin A (3) & I.8/5.0/5.0 & $2.8 / 5.0 / 5.0$ & $2.9 / 5.0 / 5.0$ & $0.8 / 1.3 /-^{\mathrm{b}}$ & $2.7 / 5.0 / 5.0$ \\
\hline Microsclerodermin B (4) & $1.4 / 5.0 / 5.0$ & $3.0 / 5.0 / 5.0$ & $3.3 / 5.0 / 5.0$ & $0.4 / 0.6 /-^{\mathrm{b}}$ & $4.3 / 5.0 / 5.0$ \\
\hline Amphotericin B & $0.6 / 2.5 / 2.5$ & $0.9 / 2.5 / 2.5$ & I.3/2.5/2.5 & $1.3 / 2.5 /-^{c}$ & $2.3 / 5.0 / 5.0$ \\
\hline
\end{tabular}

Notes: The highest test concentration for compounds $\mathbf{I - 4}$ were $20 \mu \mathrm{g} / \mathrm{mL}$. The highest test concentration for amphotericin B was $5 \mu \mathrm{g} / \mathrm{mL}$. a $\mathrm{C}_{50}, 50 \%$ growth inhibition; MIC, minimum inhibitory concentration (lowest concentration that allows no detectable growth); MFC, minimum fungicidal concentration (the lowest concentration that kills

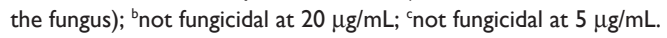

concentration (MIC) and minimum fungicidal concentration (MFC) of the four compounds were determined in comparison with the positive control amphotericin B and are shown in Table 2. Compounds $\mathbf{1}$ and $\mathbf{2}$ are less potent than compounds $\mathbf{3}$ and 4. For example, compound 4 had MICs of 5.0, 5.0, 5.0, 0.6 , and $5.0 \mu \mathrm{g} / \mathrm{mL}$, comparable to amphotericin $\mathrm{B}$, with MICs of 2.5, 2.5, 2.5, 2.5, and $5.0 \mu \mathrm{g} / \mathrm{mL}$ against $C$. albicans, C. glabrata, C. krusei, A. fumigatus, and C. neoformans, respectively. It is important to note that the four compounds are fungicidal against tested Candida species and Cryptococcus neoformans, which represent typical opportunistic fungal pathogens associated with immunosuppressed hosts. ${ }^{2,4}$

Previous studies have described antifungal activity of microsclerodermins against $C$. albicans in a paper disk assay. ${ }^{5-7}$ Relative antifungal potencies of compounds were reported; eg, microsclerodermins A (3) and B (4) inhibited the growth of $C$. albicans at $2.5 \mu \mathrm{g} /$ disk. ${ }^{5}$ Our antifungal testing method has shown that these two compounds indeed exhibited similar, strong antifungal potency when compared with the antifungal drug amphotericin B (Table 2), indicating that this class of compounds may warrant further study as potential antifungal leads.

\section{Experimental section General experimental procedure}

Optical rotations were measured with an Autopol IV polarimeter. UV was obtained from an HP 8453 diode array spectrophotometer. IR spectra were recorded using a Thermo Nicolet IR 300 FT/IR spectrometer. The 1D and 2D NMR (DQF-COSY, HMQC, HMBC, and ROESY) spectra using standard pulse programs were recorded at room temperature on a Varian Oxford AS400 spectrometer, operating at $400\left({ }^{1} \mathrm{H}\right)$ and $100\left({ }^{13} \mathrm{C}\right) \mathrm{MHz}$, or on a Bruker Avance DRX $500 \mathrm{FT}$ spectrometer, operating at $500\left({ }^{1} \mathrm{H}\right)$ and $125\left({ }^{13} \mathrm{C}\right) \mathrm{MHz}$. The chemical shift values are relative to the internal standard TMS. HRESIMS data were obtained on an Agilent Series 1100 SL mass spectrometer. Column chromatography was performed using reversed-phase silica gel (RP-18, $40 \mu \mathrm{m}$; J T Baker, USA). Semi-preparative HPLC was conducted on a C18 column (Gemini, $250 \times 10 \mathrm{~mm}$ id, $5 \mu \mathrm{m}$ particle size; Phenomenex Inc, USA) with UV detection at $254 \mathrm{~nm}$. TLC was carried out on silica gel sheets (Alugram ${ }^{\circledR}$ Sil G/UV ${ }_{254}$; Macherey-Nagel, Germany) and reversed-phase plates (RP-18 $\mathrm{F}_{254 \mathrm{~S}}$; Merck, Germany) and visualized by spraying $10 \% \mathrm{H}_{2} \mathrm{SO}_{4}$ followed by heating. $N$ - $\alpha$-(2,4-Dinitro-5-fluorophenyl)-Lalaninamide (L-FDAA), D- and L-tryptophan were purchased from Sigma (Milwaukee, WI).

\section{LC-MS analysis}

ESI-MS spectra were acquired using a FinniganMat $\mathrm{LCQ}^{\mathrm{TM}}$ (Thermo Scientific, Waltham, MA). The mass detector was an ion trap analyzer equipped with an ESI interface. The MS conditions were optimized with the sheath gas at 20 arbitrary units (AU), auxiliary gas at $5 \mathrm{AU}$, capillary temperature at $250^{\circ} \mathrm{C}$, electrospray voltage of the ion source at $4.5 \mathrm{kV}$, capillary voltage at $30 \mathrm{~V}$, and tube lens offset voltage at $-20 \mathrm{~V}$. ESI was operated in the positive ion mode. Full-scan spectra were acquired over a 300-2000 m/z range. Chromatographic analysis was conducted at ambient temperature, and the data was analyzed using Xcalibur software. The HPLC system consisted of a quaternary pump (model TSP P4000), an autosampler (model TSP AS3000), and a diode-array detector (model TSP UV6000). Separation was achieved on a Gemini C18 column $(150 \times 4.6 \mathrm{~mm}$ id, $5 \mu \mathrm{m}$ particle size; Phenomenex Inc) at room temperature. The column was equipped with a $2 \mathrm{~cm}$ Phenomenex LC-18 guard column. The mobile phase consisted of (A) $0.1 \%$ formic acid in water and (B) $0.1 \%$ formic acid in $\mathrm{CH}_{3} \mathrm{CN}$ at a flow rate of $1.0 \mathrm{~mL} / \mathrm{min}$; the gradient elution was as follows: $0-25 \mathrm{~min}, 20 \% \mathrm{~A}: 80 \%$ B to $65 \%$ A:35\% B; $25-27$ min, $65 \%$ A:35\% B to $100 \%$ A; 27-35 min, $100 \%$ A. Each run was followed by an 8-minute wash with $100 \% \mathrm{CH}_{3} \mathrm{CN}$ and a re-equilibration with $20 \%$ A: $80 \%$ B for 15 minutes, respectively. The injection volume was $10 \mu \mathrm{L}$ at a concentration of $50 \mu \mathrm{g} / \mathrm{mL}$. 


\section{Biological material}

A specimen of the lithistid sponge Microscleroderma herdmani was collected in Mauritius (latitude 20 $0^{\circ} 17.60^{\prime} \mathrm{S}$, longitude $057^{\circ} 21.06^{\prime} \mathrm{E}$ ) at a depth of $45 \mathrm{~m}$ under sea on November 13 , 1999. A voucher specimen was deposited in the Smithsonian Institute, Washington DC (voucher \#0CDN6936). The NCI received the material on December 2, 1999, from which a $\mathrm{CHCl}_{3}-\mathrm{MeOH}$ (1:1) extract (coded as C019611) was prepared by an extraction protocol described previously. ${ }^{11}$

\section{Isolation of antifungal compounds}

The organic extract $(2.770 \mathrm{~g})$ was chromatographed on a reversed-phase $\mathrm{C} 18$ column (RP-18 silica gel, $70 \mathrm{~g}$ ), using stepwise gradient elution of $\mathrm{MeOH}-\mathrm{H}_{2} \mathrm{O}(0 \%, 25 \%$, $50 \%, 75 \%$, and $100 \%$ ) to afford five fractions (Fr. A-E). Fr. C $(50 \% \mathrm{MeOH}$ eluate, $0.203 \mathrm{~g})$ showed $\mathrm{IC}_{50} \mathrm{~s}$ of 1.6 , 9.3, and $1.9 \mu \mathrm{g} / \mathrm{mL}$ against $C$. albicans, C. neoformans, and A. fumigatus, respectively, while Fr. D $(75 \% \mathrm{MeOH}$ eluate, $0.184 \mathrm{~g}$ ) gave $\mathrm{IC}_{50} \mathrm{~s}$ of $2.9,17.8$, and $3.1 \mu \mathrm{g} / \mathrm{mL}$ against the aforementioned three fungal pathogens. Upon semi-preparative, reversed-phase HPLC separation using $43 \%$ aqueous $\mathrm{CH}_{3} \mathrm{CN}$ in $0.1 \%$ trifluoracetic acid, Fr. $\mathrm{C}$ afforded microsclerodermins A (3, 54.6 mg) and B (4, $71.6 \mathrm{mg}$ ), while Fr. D gave microsclerodermins J (1, $10.4 \mathrm{mg})$ and $\mathrm{K}(\mathbf{2}, 8.0 \mathrm{mg})$.

Microsclerodermin J (1): amorphous white powder, $[\alpha]_{\mathrm{D}}^{25}-57.3$ (c 0.12, 1:5 0.1 $\mathrm{N}$ aqueous $\left.\mathrm{NH}_{4} \mathrm{HCO}_{3} / \mathrm{MeOH}\right)$; $\mathrm{UV}(\mathrm{MeOH}) \lambda_{\text {max }}(\log \varepsilon) 205$ (4.78), 264 (4.23); IR $v_{\max } 3285$, 2917, 2850, 1649, 1510, 1462, 1249, 1174, 1069, 867, 839, $789,718 \mathrm{~cm}^{-1}$; NMR data (DMSO- $d_{6}$ ): Table 1; HRESIMS $\mathrm{m} / z 917.4528$ (calcd for $\left[\mathrm{C}_{46} \mathrm{H}_{60} \mathrm{~N}_{8} \mathrm{O}_{12}+\mathrm{H}\right]^{+}$, 917.4409).

Microsclerodermin $\mathrm{K}(2)$ : amorphous white powder, $[\alpha]^{25}-78.2\left(c 0.12,1: 50.1 \mathrm{~N}\right.$ aqueous $\mathrm{NH}_{4} \mathrm{HCO}_{3} /$ $\mathrm{MeOH}) ; \mathrm{UV}(\mathrm{MeOH}) \lambda_{\max }(\log \varepsilon) 204$ (4.72), 262 (4.53); IR (KBr) $v_{\text {max }} 3298,2920,2851,1650,1510,1461,1336$, 1248, 1174, 1087, 1023, 801, 745, $719 \mathrm{~cm}^{-1}$; NMR data (DMSO- $d_{6}$ ): Table 1; HRESIMS $\mathrm{m} / \mathrm{z} 931.4124$ (calcd for $\left[\mathrm{C}_{46} \mathrm{H}_{60} \mathrm{~N}_{8} \mathrm{O}_{13}-\mathrm{H}\right]^{-}$, 931.4202).

\section{Determination of absolute configuration of tryptophan in microsclerodermin $\mathrm{K}(2)$} A solution of compound $2(0.9 \mathrm{mg})$ in $6 \mathrm{~N} \mathrm{HCl}(1 \mathrm{~mL})$ was heated in a sealed tube at $110^{\circ} \mathrm{C}$ for 24 hours. After cooling, the solvent was removed by a stream of dry nitrogen gas. The residue was further dried in vacuo and dissolved in $50 \mu \mathrm{L}$ water. To this solution, $20 \mu \mathrm{L}$ of $1 \mathrm{M}$ sodium bicarbonate and $100 \mu \mathrm{L}$ of $1 \% \mathrm{~L}-F D A A$ in acetone were added. The solution was incubated at $37^{\circ} \mathrm{C}$ for 1 hour. The reaction was quenched by adding $20 \mu \mathrm{L} 1 \mathrm{M} \mathrm{HCl}$. The reaction mixture was diluted with $810 \mu \mathrm{L} \mathrm{MeOH}$, and $5 \mu \mathrm{L}$ of the resultant solution was subjected to HPLC analysis. The standard amino acids L- and D-tryptophan $(0.3 \mathrm{mg}$ each) were treated in the same manner. The HPLC analysis was carried out on a Discovery C18 column $(150 \times 4.6 \mathrm{~mm}, 5 \mu \mathrm{m}$; Supelco, PA) at ambient temperature, using a mobile phase of $\mathrm{CH}_{3} \mathrm{CN}$ and $0.1 \%$ trifluoracetic acid in water at a flow rate of $1 \mathrm{~mL} / \mathrm{min}$ under a linear gradient elution, starting from $25 \%$ to $65 \% \mathrm{CH}_{3} \mathrm{CN}$, for 45 minutes. A diode-array detector at $340 \mathrm{~nm}$ was used for detection. The retention times for L-tryptophan-FDAA and D-tryptophan-FDAA were 22.9 and 25.8 minutes, respectively. Identification of L-tryptophan in compound $\mathbf{2}$ was made by spiking the standard L-tryptophan-FDAA and D-tryptophan-FDAA in the derivatized hydrolysis products.

\section{Antifungal assay}

The organisms were obtained from the American Type Culture Collection (Manassas, VA), and included Candida albicans ATCC 90028, C. glabrata ATCC 90030, C. krusei ATCC 6258, Cryptococcus neoformans ATCC 90113, and Aspergillus fumigatus ATCC 204305. All organisms were tested using modified versions of the CLSI (formerly NCCLS) methods. ${ }^{9,10}$ For all organisms, excluding A. fumigatus, optical density was used to monitor growth. Media supplemented with 5\% Alamar Blue ${ }^{\mathrm{TM}}$ (BioSource International, Camarillo, CA) was used for growth detection of A. fumigatus. Samples (dissolved in DMSO) were serially-diluted in $20 \% \mathrm{DMSO} /$ saline and transferred $(10 \mu \mathrm{L})$ in duplicate to 96-well, flat-bottom microplates. Inocula were prepared by correcting the $\mathrm{OD}_{630}$ of microbe suspensions in incubation broth. Amphotericin B (ICN Biomedicals, OH) was included as a positive control in each assay. The growth of all organisms was read at either $530 \mathrm{~nm}$, using the Biotek Powerwave XS plate reader (Bio-Tek Instruments, VT), or 544ex/590em, (A. fumigatus), using the Polarstar Galaxy Plate Reader (BMG LabTechnologies, Germany) prior to and after incubation at $35^{\circ} \mathrm{C} . \mathrm{IC}_{50} \mathrm{~s}$ (concentrations that afford 50\% inhibition relative to controls) were calculated using XLfit 4.2 software (IDBS, Alameda, CA), using fit model 201. The MIC is defined as the lowest test concentration that allows no detectable growth (for A. fumigatus, no color change from blue to pink). MFCs were determined by removing $5 \mu \mathrm{L}$ from each clear (or blue) well, transferring to fresh media, and incubating at $35^{\circ} \mathrm{C}$ for $2-3$ days. The MFC is defined as the lowest test concentration that kills the organism (allows no growth). 


\section{Acknowledgment}

The authors would like to thank the Natural Products Branch Repository Program at the National Cancer Institute for providing the marine extract from the NCI Open Repository, Ms Marsha Wright for antifungal testing, Dr Bharathi Avula for recording HRESI-MS spectra, Mr Frank T Wiggers for obtaining some NMR spectra, and Dr Wenhui Xu and $\mathrm{Mr}$ Xiang Fu for technical assistance of HPLC analysis. This work was supported by the NIH, NIAID, Division of AIDS, Grant No AI 27094, and the USDA Agricultural Research Service Specific Cooperative Agreement No 58-6408-2-0009.

\section{Disclosure}

The authors report no conflicts of interest in this work.

\section{References}

1. Wisplinghoff H, Bischoff T, Tallent SM, Seifert H, Wenzel RP, Edmond MB. Nosocomial bloodstream infections in US hospitals: analysis of 24,179 cases from a prospective nationwide surveillance study. Clin Infect Dis. 2004;39(3):309-317.

2. Lattif AA, Swindell K. History of Antifungals. In: Ghannoum MA, Perfect JR, editors. Antifungal Therapy. New York: Informa Healthcare; 2010:1-10.
3. Mukherjee PK, Wang M. Antifungal drug resistance: significance and mechanisms. In: Ghannoum MA, Perfect JR, editors. Antifungal Therapy. New York: Informa Healthcare; 2010:63-86.

4. Venkatesan P, Perfect JR, Myers SA. Evaluation and management of fungal infections in immunocompromised patients. Dermatol Ther. 2005;18(1):44-57.

5. Bewley CA, Debitus C, Faulkner DJ. Microsclerodermins A and B. Antifungal cyclic peptides from the lithistid sponge Microscleroderma sp. J Am Chem Soc. 1994;116(17):7631-7636.

6. Schmidt EW, Faulkner DJ. Microsclerodermins C-E. Antifungal cyclic peptides from the lithistid sponges Theonella sp. and Microscleroderma sp. Tetrahedron. 1998;54(13):3043-3056.

7. Qureshi A, Colin PL, Faulkner DJ. Microsclerodermins F-I, antitumor and antifungal cyclic peptides from the lithistid sponge Microscleroderma sp. Tetrahedron. 2000;56(23):3679-3685.

8. Fujii K, Ikai Y, Mayumi T, Oka H, Suzuki M, Harada K-I. A nonempirical method using LC/MS for determination of the absolute configuration of constituent amino acids in a peptide: elucidation of limitations of Marfey's method and of its separation mechanism. Anal Chem. 1997;69(16):3346-1352.

9. NCCLS. Reference method for broth dilution antifungal susceptibility testing of yeasts; Approved standard M27-A2. National Committee on Clinical Laboratory Standards; 2002;22(15).

10. NCCLS. Reference method for broth dilution antifungal susceptibility testing of filamentous fungi; approved standard, M38-A. National Committee on Clinical Laboratory Standards; 2002:22(16).

11. DiGirolamo JA, Li XC, Jacob MR, Clark AM, Ferreira D. Reversal of fluconazole resistance by sulfated sterols from a marine sponge, Topsentia sp. 1. J Nat Prod. 2009;72(8):1524-1528.

\section{Publish your work in this journal}

Research and Reports in Medicinal Chemistry is an international, peerreviewed, open access journal publishing original research, reports, reviews and commentaries on all areas of medicinal chemistry. The manuscript management system is completely online and includes a very quick and fair peer-review system, which is all easy to use.

\section{Dovepress}

Visit http://www.dovepress.com/testimonials.php to read real quotes from published authors. 